\title{
At-sea mortality of seabirds based on beachcast and offshore surveys
}

\author{
Kelly M. Newton ${ }^{1, *}$, Donald A. Croll ${ }^{1}$, Hannahrose M. Nevins ${ }^{2}$, Scott R. Benson ${ }^{3}$, \\ James T. Harvey ${ }^{2}$, Bernie R. Tershy ${ }^{1}$ \\ ${ }^{1}$ Center for Ocean Health, University of California Santa Cruz, 100 Shaffer Rd. Santa Cruz, California 95060, USA \\ ${ }^{2}$ Moss Landing Marine Laboratories, 8272 Moss Landing Rd., Moss Landing, California 95039, USA \\ ${ }^{3}$ NOAA Fisheries, 7544 Sandholdt Rd., Moss Landing, California 95039, USA
}

\begin{abstract}
Although seabird population biology is relatively well studied, little data exists on mortality at-sea. Beached bird surveys are used to identify patterns of seabird mortality, but resulting patterns are difficult to interpret without corresponding data on at-sea density. We examined seabird mortality relative to at-sea density in Monterey Bay, California over 10 yr by integrating data from monthly beachcast seabird and offshore seabird censuses. Beachcast seabird numbers were relatively constant (mean $2.82 \pm 0.31$ seabirds $\mathrm{km}^{-1}$ ) throughout the year. At-sea seabird density (mean $148.9 \pm 16.12$ seabirds $\mathrm{km}^{-2}$ ) peaked in the summer upwelling period and was least in the winter Davidson period. A principal components analysis of seasonal climatic, prey availability, and anthropogenic variables for Monterey Bay derived 3 significant principal components (PCs) (explaining $70 \%$ of variance) characterized by storm activity and low prey availability (PC1), river discharge and krill abundance (PC2), and oiling (PC3). These principal components were used in detailed analyses of the 2 most abundant seabird species and indicate that sooty shearwater Puffinus griseus relative mortality is greatest during decreased productivity and increased storm activity. While relative mortality of common murres Uria aalge cannot be explained by the derived principal components, relative mortality increased in late winter when prey availability decreased concurrent with the annual increase in reproductive stress. Beachcast seabird data is difficult to interpret in isolation; however, when linked to at-sea densities of seabirds, it becomes a powerful tool to examine the relative impacts of oceanography and direct human perturbations on seabird demography.
\end{abstract}

KEY WORDS: Seabirds at-sea · Beached bird survey · Density · Mortality · Sooty shearwater · Common murre

\section{INTRODUCTION}

Seabirds are abundant top level marine predators that consume $7 \%$ of total marine primary productivity (Brooke 2004). Due to their low fecundity, population distribution (where much of the world's populations breed on a few islands), and sensitivity to direct and indirect human impacts, they are the most threatened group of marine species, representing $25 \%$ of all global marine extinctions (Dulvy et al. 2003, Buckelew 2007 ) with $30 \%$ of species at some risk of extinction (IUCN 2007).
Many seabird species are well studied on their breeding colonies, resulting in a good understanding of population dynamics and sources of mortality during the breeding season (Wooller et al. 1992). Most data come from capture-mark-recapture (CMR) studies conducted at breeding colonies where birds are marked one year then counted if they return in subsequent years (Bertram et al. 2000). However, patterns and causes of at-sea mortality, especially during the non-breeding season, are poorly known. Surveys of dead birds found on beaches have become a useful tool worldwide for examining mortality patterns in sea- 
birds (Roletto et al. 2003, Fleet 2006, Harris et al. 2006, Heubeck 2006, Zydelis et al. 2006, Parrish et al. 2007). An advantage of this method over CMR studies is that beached bird surveys enable researchers to examine the seabird community as a whole, including residents and migrants, away from breeding colonies, and sampling can occur year-round. Few researchers, however, have studied the correlation of the number of birds at sea to the number of birds that wash ashore (Mason 1997, Camphuysen \& Heubeck 2001). For example, in November 2003, Nevins \& Harvey (2003) reported a mass mortality event of northern fulmars Fulmarus glacialis in Monterey Bay, California. Two possible scenarios explain the event: (1) it was a mass mortality event, or (2) mortality was normal and there was an extraordinary influx of northern fulmars into Monterey Bay. Scaling beachcast density to at-sea density as a per capita mortality rate allows us to discern between these 2 possible scenarios, which have different management implications, and is important for understanding the effects of various environmental factors on seabird mortality.

Here we investigate the relationship between seabird numbers at-sea, beachcast seabirds, and oceanographic conditions in Monterey Bay, California during a 10 yr period. Specifically, we (1) examine the relationship between density of seabirds at-sea (i.e. live birds) and beachcast seabirds (i.e. dead birds), and calculate seabird mortality relative to at-sea density; and (2) develop a statistical model using physical and biological oceanographic data to identify the environmental conditions related to mortality of both a migratory and resident seabird species in Monterey Bay.

\section{MATERIALS AND METHODS}

Study area. Monterey Bay is located on the central coast of California and is a key foraging area for 45 resident and migratory seabird species. The abundance, distribution, and diversity of seabirds in relation to numerous oceanographic features and conditions have been well studied in the central California Current System (Baltz \& Morejohn 1977, Oedekoven et al. 2001, Ford et al. 2004, Yen et al. 2004, Ainley et al. 2005), and it is well established that seasonal processes affect variability in seabird density (Briggs et al. 1987, Ford et al. 2004).

Monterey Bay is characterized by 3 distinct oceanographic seasons: upwelling, oceanic, and Davidson (Skogsberg 1936, Skogsberg \& Phelps 1946). Generally, the upwelling season begins in late February to early March, extends through July, and is characterized by periods of strong northwesterly winds that are most intense in late spring and early summer. The oceanic season, August to October, is characterized by the relaxation of upwelling and the onshore movement of California Current water. The winter, or Davidson period, November through February, is characterized by the northward flow of the Davidson Current when surface waters are warm relative to the upwelling period. A number of researchers have established that seabird abundance in Monterey Bay is generally greatest during the late upwelling to early oceanic seasons (July to September), and least during the Davidson period (November to February; Briggs et al. 1987, Ford et al. 2004).

Beachcast seabird data. Monterey Bay National Marine Sanctuary BeachCOMBERS (Coastal Ocean Mammal \& Bird Education \& Research Surveys) volunteers collected monthly beachcast seabird data on 11 beaches (47.4 km, May 1997 to Aug 1998; $51.1 \mathrm{~km}$, Sept 1998 to Nov 2006) in/around Monterey Bay (Fig. 1). A pair of trained observers sampled the entire width of beaches during the first week of every month during low tide, and recorded all dead seabirds encountered in the beach strip to the lowest taxonomic level. Beachcast seabirds were marked (via toe clipping) to aid in determining recently arrived seabirds

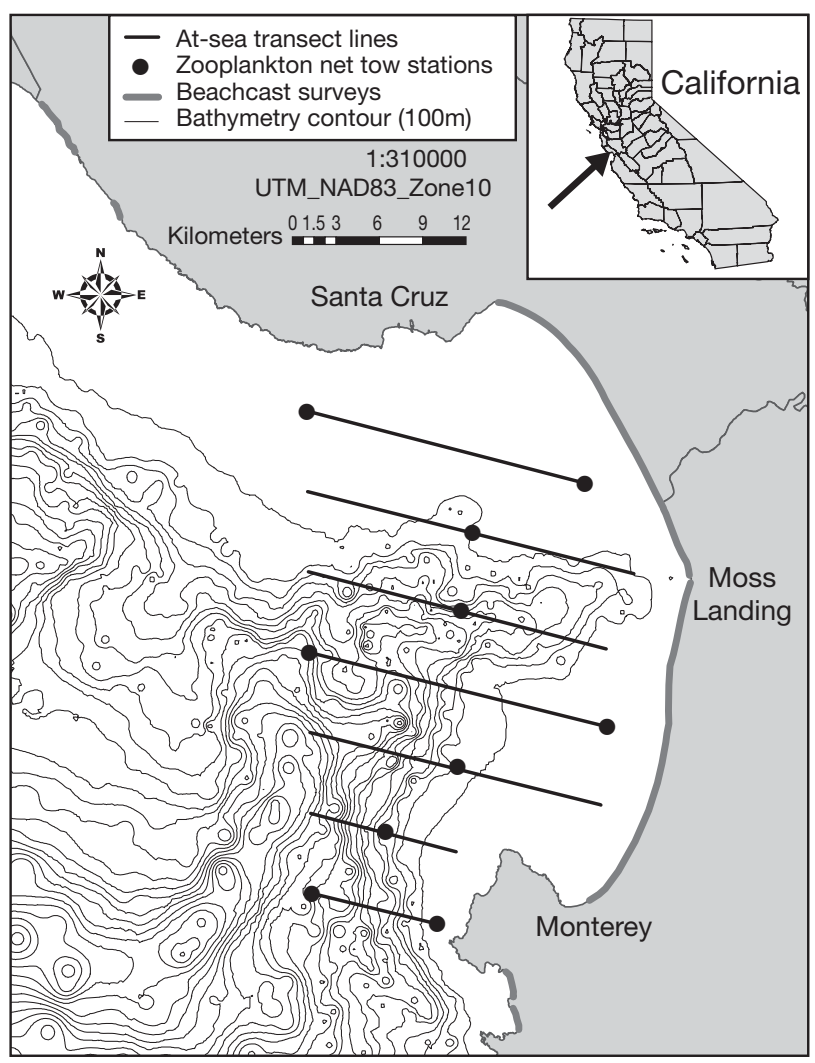

Fig. 1. Monterey Bay, California, USA. Black lines: at-sea transect lines; Black circles: locations of zooplankton net tows; Beaches surveyed for beachcast seabirds are shaded in grey 
on the beach (birds that were not recorded during the previous months survey) and residence times of dead beachcast seabirds. The analyses include only recently arrived seabirds. Because the same beaches were sampled throughout the study period, the overall area of beach surveyed remained relatively constant throughout the study.

At-sea seabird data. At-sea seabird data were collected by the Wind to Whales program jointly run by the University of California Santa Cruz, Moss Landing Marine Laboratories, and the Center for Integrated Marine Technologies. Data were collected monthly from May through November, from 1997 to 2006, in Monterey Bay, California. Beginning in 2003, surveys during January and March were added to sample the winter and early spring conditions in the bay. Details of methods are presented in Benson (2002). Seven transect lines (9.26 to $22.22 \mathrm{~km}$ in length and spaced $5.56 \mathrm{~km}$ apart: $120 \mathrm{~km}$ total; Fig. 1) were completed during each survey using strip transect methods (Buckland et al. 2001). All seabirds encountered along on one side of the research vessel (the side with best sighting conditions) perpendicular to the vessel and out to $100 \mathrm{~m}$ were identified to the lowest possible taxon. Transect strip width was estimated by the observer via a small handheld rangefinder as described by Heinemann (1981), and search effort was focused on the area ahead of the vessel to allow for the detection of seabirds that may dive evasively as a reaction to the vessel. Seabirds that flew into the transect strip as a result of being flushed by the vessel were not counted. Seabirds following the ship were counted if they approached the ship and flew into the strip, and were counted only once. Seabird behavior (sitting or flying) was recorded; however, the data were not corrected for bird 'flux' (Spear et al. 1992) because flight direction was not recorded for flying seabird observations. We calculated seabird densities (ind. $\mathrm{km}^{-2}$ ) for each monthly survey. Seventy-six corresponding atsea and beachcast seabird surveys were conducted during the study period: January and March (2003 to 2006), and May to November (1997 to 2006).

Seabird species selection. Because survey tracklines did not extend into the near-shore region (the shoreward terminus of transect lines was at the $55 \mathrm{~m}$ isobath), seabirds found in this habitat (e.g. grebes Aechmophorus sp., surf scoters Melanitta perspicillata, cormorants Phalacrocorax sp., and brown pelicans Pelecanus occidentalis) were rarely observed during at-sea surveys. We restricted our analyses, therefore, to species that commonly used waters deeper than $55 \mathrm{~m}$ and were adequately sampled in both beachcast and at-sea surveys (Table 1). Thus, we examined relative mortality patterns for the 2 most common species, the sooty shearwater Puffinus griseus, a seasonal
Table 1. Percentage of seabirds encountered at-sea during Wind to Whales surveys and beachcast during BeachCOMBERS surveys

\begin{tabular}{|lrc|}
\hline \multirow{2}{*}{ Species } & \multicolumn{2}{c|}{ \% of total } \\
\cline { 2 - 3 } & At-sea & Beachcast \\
\hline Sooty shearwater & 69.08 & 12.22 \\
Common murre & 13.09 & 33.97 \\
Unidentified gulls & 2.41 & 4.67 \\
Western gull & 2.14 & 3.74 \\
Red-necked phalarope & 2.04 & 0.07 \\
Rhinoceros auklet & 1.77 & 0.88 \\
California gull & 1.58 & 2.28 \\
Brandt's cormorant & 1.26 & 8.11 \\
Cassin's auklet & 1.04 & 1.55 \\
Heermann's gull & 0.83 & 0.55 \\
Brown pelican & 0.67 & 2.09 \\
Pink-footed shearwater & 0.48 & 0.12 \\
Black-vented shearwater & 0.45 & 0.05 \\
Northern fulmar & 0.38 & 11.91 \\
All other species & 2.73 & 17.81 \\
\hline
\end{tabular}

migrant to Monterey Bay, and the common murre Uria aalge, a year round central California resident species.

Environmental variables. We used a suite of environmental variables to assess the relationship between environmental conditions and relative seabird mortality in Monterey Bay. Storm events, lack of prey, and direct anthropogenic impacts are potentially important factors in at-sea mortality of seabirds during the non-breeding season. Thus, we selected variables indicative of seasonal climatic conditions, prey availability, and anthropogenic effects. Although other causes of mortality such as disease, predation, and senescence also may be important in at-sea mortality, they are difficult to quantify and thus not included in the analyses. Variables used to describe seasonal climatic conditions included indicators of storm activity: river discharge, wave height, and tidal height + wave height. Wind speed was not included as an environmental variable because it is a poor indicator of storms due to the strong northwesterly winds that occur during the spring and summer months. An upwelling index, primary production, zooplankton biovolume, and krill backscatter were used as indicators of prey availability. Fishing effort (sets per month, for the California halibut set gillnet fishery) and an index of oiled seabirds were included as indicators of important anthropogenic effects. For model parameter inputs, environmental variables were either sampled monthly (e.g. zooplankton biovolume, krill backscatter) or averaged across the entire month to derive a single monthly value (e.g. upwelling index, primary production, wave height).

Climate variables. Monthly river discharge data $\left(\mathrm{ft}^{3} \mathrm{~s}^{-1}\right)$ from the San Lorenzo River in Santa Cruz, California, were downloaded from the US Geological Survey 
website: http://waterdata.usgs.gov. Wave height was obtained from NOAA's National Data Buoy Center for the Monterey buoy, Stn $46042\left(36.75^{\circ} \mathrm{N}, 122.42^{\circ} \mathrm{W}\right)$. Monthly means were calculated using the significant wave height, which was the average of the highest onethird of all of the wave heights during a 20 min sampling period (http://seaboard.ndbc.noaa.gov/station_history. php?station=46042). A combination of tidal height plus wave height was used to indicate months with heavy beach scouring (when carcasses were removed from the beach due to the combination of high waves and high tides). We calculated this parameter as the number of days per month when tidal height plus wave height was $>4 \mathrm{~m}$. The maximum daily tidal height for the Monterey Stn (number 9413450) (in meters referenced to mean lower low water) was downloaded from the NOAA Tides and Currents website: http://tidesandcurrents.noaa.gov.

Prey availability variables. The monthly upwelling index $\left(\mathrm{m}^{3} \mathrm{~s}^{-1} 100 \mathrm{~m}^{-1}\right.$ coastline) for the Monterey Bay region $\left(36^{\circ} \mathrm{N}, 122^{\circ} \mathrm{W}\right)$ was derived by the NOAA Fisheries Service, Environmental Research Division (www. pfeg.noaa.gov). Ocean color (Sea-Viewing Wide Field Sensor, SeaWiFS, and Moderate Resolution Imaging Spectrometer, MODIS AQUA) data were obtained from the NASA Ocean Biology Processing Group (OBPG). Depth-integrated primary production $\left(\mathrm{mg} \mathrm{C} \mathrm{m} \mathrm{m}^{-2} \mathrm{~d}^{-1}\right)$ was derived for monthly averages of a $3 \times 3$ pixel $\left(9 \mathrm{~km}^{2}\right)$ region centered on the Monterey Bay Aquarium Research Institute M1 mooring $\left(36.75^{\circ} \mathrm{N}\right.$, $122.03^{\circ} \mathrm{W}$ ) using data from 1997 to 2006, processed with the standard OBPG methods for chlorophyll and the standard vertically generalized production model (VGPM) for primary production, described by Behrenfeld \& Falkowski (1997), and modified to use a nonvarying $P^{\mathrm{B}}{ }_{\text {opt }}$ term as described by Kudela et al. $(2006 a, b)$. Zooplankton biovolume (total zooplankton displacement volume) was calculated based on conventional net sampling as described in Marinovic et al. (2002). Plankton tows using Bongo nets or tucker trawls (333 $\mu \mathrm{m}$ mesh) were towed obliquely to $200 \mathrm{~m}$ or to 10 $\mathrm{m}$ above the bottom. A General Oceanics flow meter was used to estimate the volume of water filtered. Monthly mean zooplankton biovolume (ml $1000 \mathrm{~m}^{-3}$ ) was calculated as the average total zooplankton displacement volume across all sampled stations (Fig. 1). Krill acoustic backscatter was calculated based on the methods described in Croll et al. (1998) and Hewitt \& Demer (1993). During at-sea surveys, krill backscatter was integrated for every 0.5 nautical mile (nmi) transect segment to a depth of $200 \mathrm{~m}$ or $5 \mathrm{~m}$ above the bottom using a SIMRAD EY500 or EK60 digital scientific echosounder operating at $200 \mathrm{kHz}$. Calibration of the system was performed yearly using the standard sphere method (Johannesson \& Mitson 1983). Krill backscatter is defined as the mean nautical area scat- tering coefficient $\left(\mathrm{m}^{2} \mathrm{nmi}^{-2}\right)$ of krill for all transect segments during each monthly survey.

Anthropogenic effects. Fishing effort (sets per month) was obtained from the California Department of Fish and Game logbooks for the California halibut Paralichthys californicus set gillnet fishery in Monterey Bay, California. These data were made available by NOAA Fisheries, Southwest Fishery Science Center. Fishing effort data was only included in the analyses for common murres because they were the seabird species most affected by the fishery (Forney et al. 2001). To examine the effects of oil pollution on the deposition rate of beachcast seabirds, a simple binary index was used for each month where 1 = oiled seabirds found on a beach during monthly beachcast survey, and $0=$ no oiled seabirds found.

Data analysis. All statistical analyses were conducted using Systat software (SYSTAT 2007). Data were evaluated for normality and, when necessary, log transformed to fit parametric model assumptions (see Table 2). We conducted a cross-correlation time series analysis to determine the lag between the densities of birds at-sea and deposition rates of beachcast seabirds on shore. If a significant 1 mo lag was indicated, data from the following month were used in the analyses. For example, at-sea data from October were analyzed with beachcast data from November. For common murres and sooty shearwaters, cross-correlation time series analysis indicated a significant 1 mo lag between seabird densities at-sea and deposition of beachcast seabirds onshore. The analyses, therefore, were conducted with the beachcast seabird data from the month following the at-sea survey.

To examine seabird mortality relative to at-sea density, we calculated a relative mortality index for all seabird species combined, sooty shearwaters, and common murres. The relative mortality index was calculated as the quotient of beachcast seabird density and the sum of beachcast seabird and at-sea seabird densities:

Table 2. Pearson correlation coefficients (r values) between 7 environmental variables. $N=63$ survey months. Significant correlations $(\mathrm{p}<0.05)$ are shown in bold. UPW = upwelling in$\operatorname{dex}_{i} \mathrm{PP}=$ primary production; $\mathrm{ZBV}=\log _{10}$ zooplankton biovolume; KBS $=\log _{10}$ krill acoustic backscatter; WVHT $=\log _{10}$ wave height; $\mathrm{T}+\mathrm{W}=$ tidal height + wave height; $\mathrm{RVR}=\log _{10}$ river discharge

\begin{tabular}{|lrrrrrr|}
\hline & UPW & PP & ZBV & KBS & WVHT & T+W \\
\hline PP & $\mathbf{0 . 4 7}$ & & & & & \\
ZBV & $\mathbf{0 . 6 5}$ & 0.26 & & & & \\
KBS & 0.29 & 0.22 & 0.33 & & & \\
WVHT & $\mathbf{- 0 . 4 6}$ & $\mathbf{- 0 . 3 7}$ & -0.32 & -0.32 & & \\
T+W & -0.29 & -0.34 & -0.16 & -0.15 & $\mathbf{0 . 5 1}$ & \\
RVR & -0.17 & -0.23 & -0.15 & -0.12 & $\mathbf{0 . 5 2}$ & $\mathbf{0 . 7 3}$ \\
\hline
\end{tabular}


Relative Mortality Index =

beachcast density / (beachcast density + at-sea density)

The sum of beachcast density and at-sea density was used as a divisor in order to eliminate the potential for an undefined value if the at-sea density was equal to 0 . This relative mortality index varied between 0 and 1 , with values closer to 0 resulting when beach mortality was low compared with at-sea density, and values closer to 1 resulting when beach mortality was great compared with at-sea density. Values of 0 resulted when seabirds were not found in beach surveys.

Due to the likelihood of multicolinearity between environmental variables, we calculated Pearson correlation coefficients for the seasonal climatic and prey availability variables, excluding anthropogenic effects. Because several of the seasonal climatic and prey availability variables were significantly correlated (Table 2), principal components analysis (PCA) was used to combine the suite of variables into a subset of orthogonal variables (Quinn \& Keough 2002, Graham 2003). These principal components were then used as independent variables in a multiple linear regression (MLR) to examine their effect on relative seabird mortality (dependent variable) of common murres and sooty shearwaters for the entire $10 \mathrm{yr}$ data set.

A set gillnet fishery with significant levels of common murre bycatch (Forney et al. 2001) operated during the 1997 to 2001 portion of our data set. After 2001, new state regulations prohibited set gillnet fishing in Monterey Bay. To account for this fishery closure, we included fishing effort as a variable, and split our time series into the 5 yr period (1997 to 2001) when the fishery was in operation and the subsequent $5 \mathrm{yr}$ period (2002 to 2006) after the closure of the fishery. We conducted separate PCAs and MLRs during these time periods to include the effect of fishing mortality on the relative mortality of common murres in our analyses of the earlier time period. An alpha level of 0.05 was used for all statistical tests; unless otherwise noted, mean values $\pm \mathrm{SE}$ are presented.

A limitation of using PCA is if one variable has a missing value for one of the samples, then a value for the entire sample is not calculated. Because only 63 of our 76 mo of beachcast and at-sea data were sampled with environmental data, some corresponding surveys were excluded from the principal components analysis. These included El Niño and La Niña months (May-September 1997, November 1997, May-June 1998, and MayAugust 1999). The missing data for May to September 1997 were attributed to the lack of satellite information during that time period. For November 1997, and the 1998 and 1999 time periods listed above, data were missing due to the lack of wave height data when the NOAA Monterey Buoy (buoy 46042) was out of service.

\section{RESULTS}

\section{Monthly densities and relative mortality}

All seabirds. The overall mean beachcast seabird density was $2.82 \pm 0.31$ seabirds $\mathrm{km}^{-1}$ for the months with corresponding at-sea surveys. Beachcast seabird numbers were relatively constant throughout the year with increased numbers during the early upwelling, oceanic, and Davidson periods (Fig. 2a). Beachcast density was most variable from May to August ( $\mathrm{SE}=$ 0.84 to 1.3$)$, with additional relative high variability also occurring in November ( $\mathrm{SE}=1.1$ ). Variability was less in other months ( $\mathrm{SE}=0.24$ to 0.56 ).

Overall mean at-sea seabird density was $148.9 \pm$ 16.12 seabirds $\mathrm{km}^{-2}$. At-sea seabird density in Monterey Bay peaked during the upwelling period and was least during the winter Davidson period (Fig. 2b). In addition, it was most variable during May, June, and July (upwelling season; SE $=41.7$ to 64.9) compared with October to March ( $\mathrm{SE}=6.2$ to 7.7 ).

Based on our relative mortality index, beachcast seabird numbers relative to at-sea density was greatest during the winter Davidson period and at the onset of the upwelling period. Relative mortality was least between mid-upwelling and oceanic periods (Fig. 2c). The importance of examining beachcast mortality relative to offshore density using a relative mortality index was demonstrated in an incident in November 2003 when an anomalous influx of great numbers of

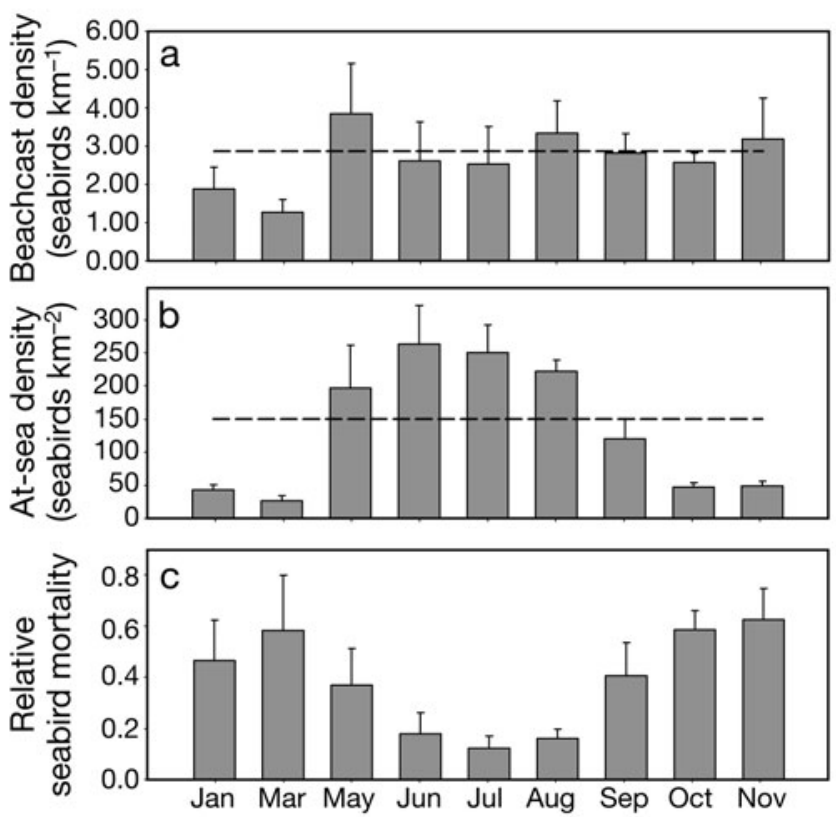

Fig. 2. Monthly means \pm SE for (a) beachcast seabird density, (b) at-sea seabird density, and (c) relative seabird mortality. Data from Jan \& Mar 2003-2006 and May-Nov 1997-2006. Dashed lines: overall mean density 
northern fulmars Fulmarus glacialis were encountered in beachcast surveys (Nevins \& Harvey 2003). Although the numbers of beachcast fulmars were exceptionally increased during this time period (November 2003, January 2004, and March 2004; Fig. 3a), their atsea density was also exceptionally increased: well above the long-term average (Fig. 3b). Thus, relative mortality values were not exceptionally great (Fig. 3c) and a shift in the at-sea distribution of fulmars was likely an important factor in the high number of beachcast birds observed during this period.

Sooty shearwaters. Sooty shearwaters were the third most abundant beachcast seabird ( 0.38 birds $\left.\mathrm{km}^{-1}\right)$, with carcasses first arriving during the upwelling season and at a maximum during the mid upwelling season. Carcass numbers decreased during the oceanic and Davidson periods (Fig. 4a). Sooty shearwaters were the most abundant seabird at-sea and were $69 \%$ of the overall at-sea density with a mean density of 103.25 birds $\mathrm{km}^{-2}$. Its at-sea density peaked during the upwelling period and subsequently decreased during the oceanic season (Fig. 4b), while its relative mortality was greatest during October, January, and March (Fig. c).

Common murres. Common murres were the most abundant beachcast seabird with a mean encounter
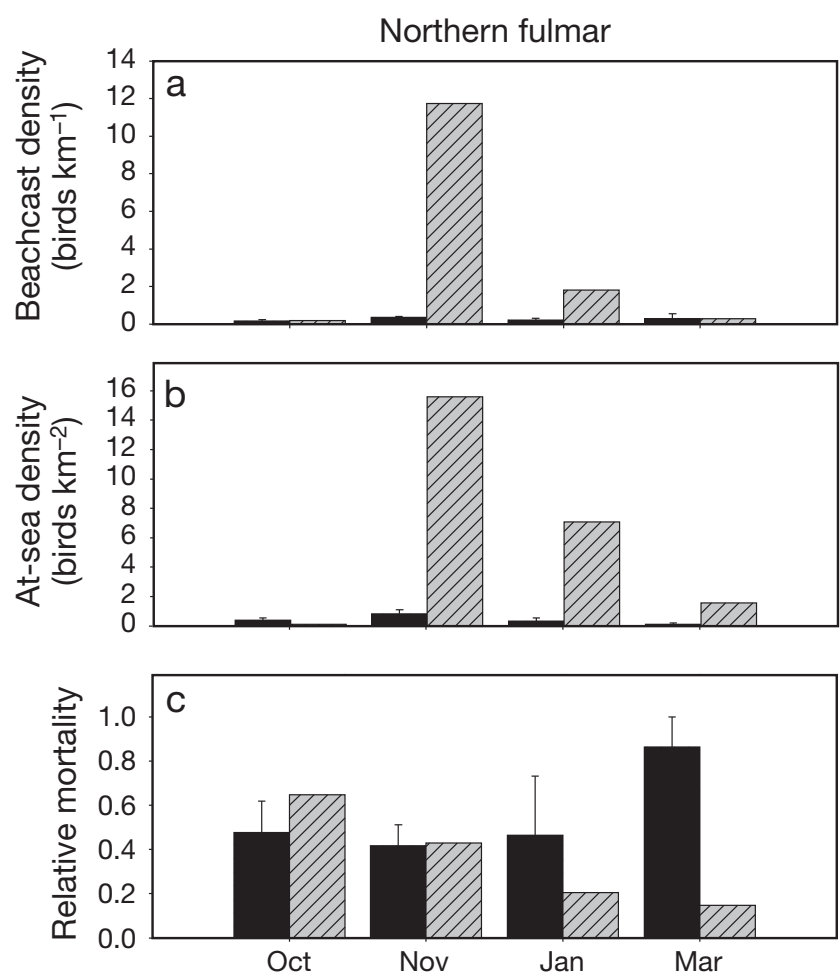

Fig. 3. Fulmarus glacialis. Long-term (1997-2002 \& 2004-2006) monthly means for October-March (solid black bars \pm SE) compared to values during the 2003-2004 event (striped grey bars) for (a) beachcast density, (b) at-sea density and (c) relative mortality

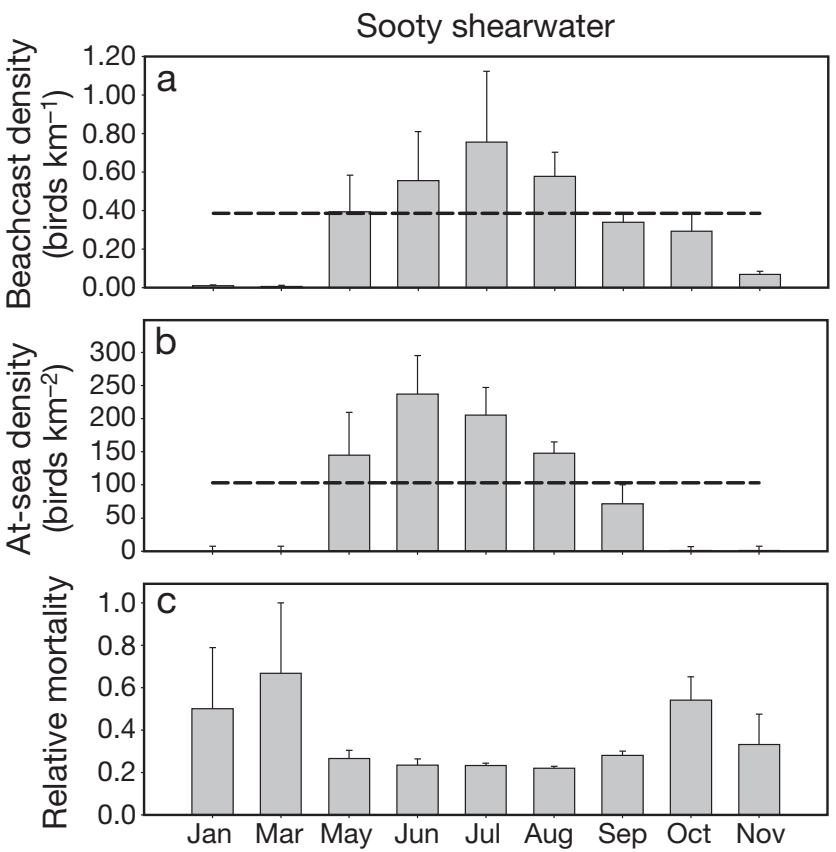

Fig. 4. Puffinus griseus. Monthly means ( $\pm \mathrm{SE}$ ) for (a) beachcast density, (b) at-sea density, and (c) relative mortality. Data from same months as Fig. 2. Dashed lines: overall mean density

rate of 1.06 birds $\mathrm{km}^{-1}$. Beachcast density peaked during both the mid upwelling (May) and oceanic seasons (Fig. 5a), and was least during the Davidson period. The common murre was the second most abundant seabird at-sea (19.51 seabirds $\mathrm{km}^{-2}$ ), and was $13 \%$ of overall at-sea density. Common murre densities in Monterey Bay were greatest during the late upwelling and early oceanic periods, and lowest during the Davidson period (Fig. 5b). Its relative mortality was greatest during March and least during August (Fig. 5c).

\section{Principal Components Analysis}

We found significant correlations (Pearson correlations) in 7 of 21 possible combinations (33\%) of seasonal climatic and prey availability variables (Fig 6, Table 2). To avoid confounding our analyses of environmental variables due to these correlations, we used the variables to derive orthogonal principal components. A PCA for the entire time series (1997 to 2006) of seasonal climatic, prey availability, and anthropogenic variables (oiled seabird index) derived 3 significant (eigenvalues $>1$ ) PCs accounting for $70 \%$ of the variance in the data (38\% explained by PC1, 19\% by PC2, and $13 \%$ by PC3). Principal component 1 was characterized by greater storm activity and lesser prey availability, PC 2 was characterized by elevated river dis- 


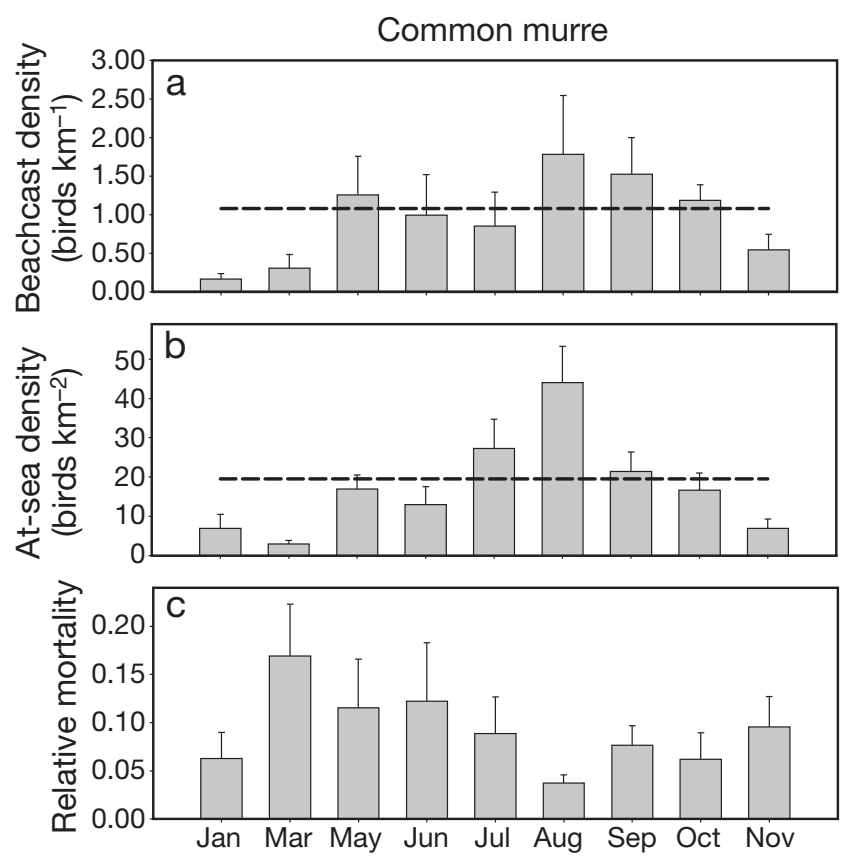

Fig. 5. Uria aalge. Monthly means ( \pm SE) for (a) beachcast density, (b) at-sea density, and (c) relative mortality. Data from same months as Fig. 2. Dashed lines: overall mean den-

charge and krill abundance, whereas PC 3 was characterized by lesser oiled seabirds incidences (Table 3 ).

When the time series was split into two 5 yr periods (1997-2001 and 2002-2006) to examine the effect of fishing effort on the mortality of common murres, we found 3 significant PCs representing $70 \%$ of the variance in the data for the fishing and $72 \%$ for non-fishing periods. When set gillnet fishing for California halibut occurred in Monterey Bay in the period 1997-2001, PC1 explained $36 \%$ of the variance and was characterized by fewer storms, greater prey availability, and lesser oiled seabird incidences (Table 4). Greater zooplankton biovolume and lesser fishing effort characterized PC2, which accounted for $19 \%$ of the variance. Principal component 3

Table 3. Component loadings for the first 3 principal components (PCs) for all 8 environmental variables (1997-2006)

\begin{tabular}{|lrrr|}
\hline \multirow{2}{*}{ Environmental variable } & \multicolumn{3}{c|}{ Component loadings } \\
& PC1 & PC2 & \multicolumn{1}{|c}{ PC3 } \\
\hline Log $_{10}$ wave height & 0.76 & 0.16 & 0.28 \\
Log $_{10}$ river discharge & 0.64 & 0.66 & 0.08 \\
Tides + waves & 0.73 & 0.45 & 0.07 \\
Upwelling index & -0.73 & 0.44 & -0.15 \\
Primary production & -0.65 & 0.13 & 0.25 \\
Log $_{10}$ zooplankton biovolume & -0.61 & 0.52 & -0.05 \\
Log $_{10}$ krill backscatter & -0.34 & 0.59 & 0.21 \\
Oiled seabirds & 0.26 & 0.21 & -0.89 \\
\hline
\end{tabular}
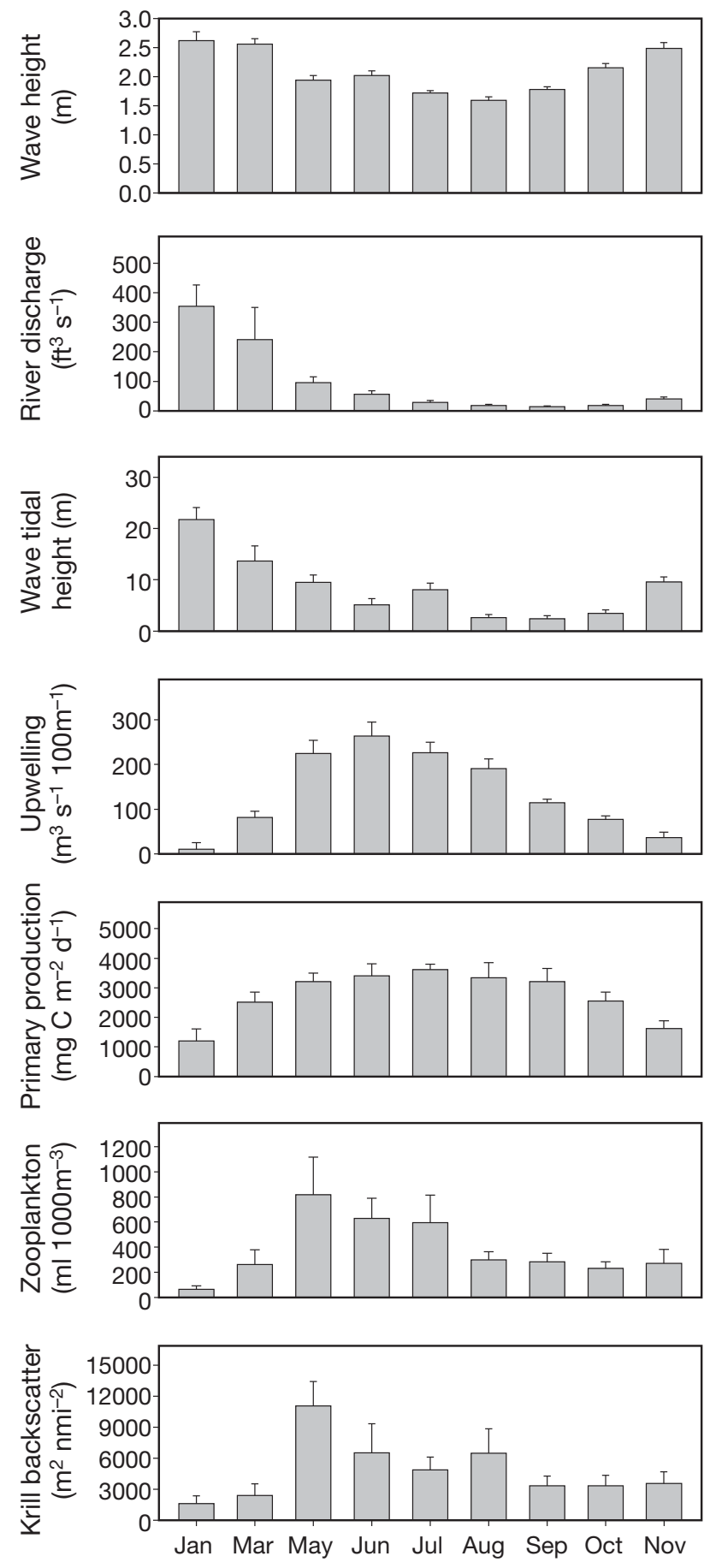

Fig. 6. Monthly means ( \pm SE) for environmental variables used in analyses of relative seabird mortality in Monterey Bay, California. Data from same months as Fig. 2. Conversion factor for river discharge: $1 \mathrm{ft}^{3}=0.0283 \mathrm{~m}^{3}$

accounted for $15 \%$ of the variance and was characterized by elevated river discharge.

For the time period 2002-2006, after the permanent closure of the gillnet fishery, results were similar to the PCA for the $5 \mathrm{yr}$ period when gillnet fishing occurred. 
Table 4. Component loadings for the first 3 principal components (PCs) for all 9 environmental variables (1997-2001 and 2002-2006)

\begin{tabular}{|lrrrrrrr|}
\hline \multirow{2}{*}{ Environmental variable } & \multicolumn{3}{c}{$1997-2001$} & \multicolumn{3}{c|}{ 2002-2006 } \\
& $\begin{array}{l}\text { Component loadings } \\
\text { PC1 }\end{array}$ & PC2 & PC3 & Component loadings \\
& & & PC1 & PC2 & PC3 \\
\hline Log $_{10}$ wave height & -0.79 & 0.12 & -0.12 & 0.78 & 0.18 & 0.26 \\
Log $_{10}$ river discharge & -0.27 & 0.19 & 0.80 & 0.69 & 0.66 & 0.00 \\
Tides + waves & -0.63 & 0.52 & 0.10 & 0.76 & 0.44 & 0.14 \\
Upwelling index & 0.85 & 0.28 & 0.06 & -0.72 & 0.48 & 0.01 \\
Primary production & 0.90 & 0.07 & -0.08 & -0.58 & 0.13 & 0.07 \\
Log $_{10}$ zooplankton biovolume & 0.25 & 0.73 & -0.20 & -0.66 & 0.50 & 0.27 \\
Log krill backscatter & 0.43 & 0.48 & 0.61 & -0.31 & 0.62 & 0.14 \\
Oiled seabirds & -0.60 & 0.22 & 0.10 & 0.04 & 0.38 & -0.91 \\
Fishing effort & 0.11 & -0.72 & 0.52 & & Not included \\
\hline
\end{tabular}

\section{DISCUSSION}

Camphuysen \& Heubeck (2001) demonstrated the utility of examining beachcast seabird information within the context of at-sea abundances. The value of merging beachcast bird mortality data with at-sea density data is illustrated by comparing beachcast bird numbers (Fig. 2a) with the relative mortality index derived by including at-sea density data (Fig. 2c). Although there is no clear pattern in beachcast mortality of all seabirds combined, the greatest relative sea-

Principal Component 1 explained $38 \%$ of the variance in the data and was characterized by greater storm events and lesser prey availability (Table 4); PC2 explained $21 \%$ of the variance and was characterized by greater river discharge and krill abundance; PC3 explained $13 \%$ of the variance and was characterized by lesser numbers of oiled seabird incidences.

\section{Multiple linear regressions}

Sooty shearwaters. In a multiple linear regression model to predict relative sooty shearwater mortality using the 3 PCs, we found PC1 and PC3 to be significant (equation: $\log _{10}$ relative mortality $=-1.72+0.52 \times$ $\left.\mathrm{PC} 1+0.25 \times \mathrm{PC} 3 ; \mathrm{F}_{2,49}=32.94, \mathrm{p}<0.05, \mathrm{r}^{2}=0.57\right)$. Thus, sooty shearwaters appeared to exhibit greater relative mortality during the time of year characterized by storms, lesser prey availability, and oiling.

Common murres. None of the 3 models we tested using our PCs to predict relative common murre mortality (all years, fishing, post-fishing) were significant. We then tested General Linear Models (GLMs) for our 9 environmental variables to determine if any one variable predicted relative mortality patterns. None of the individual GLMs for relative common murre mortality were significant for the entire 1997-2006 period. In addition, no significant relationship was found between relative common murre mortality and the 9 variables for either the gill-net fishing period (1997-2001) or the non-fishing period (2002-2006). To examine the effect of fishing effort on beachcast common murre density during the gill-net fishing period (1997 to 2001), we conducted a GLM using fishing effort as the independent variable and beachcast common murre density (delayed one month as per cross correlation time series analysis) as the dependent variable. We found a statistically significant relationship between beachcast common murres and fishing effort $\left(F_{1,32}=\right.$ 7.83, $\left.\mathrm{p}=0.008, \mathrm{r}^{2}=0.19\right)$. bird mortality occurs between late fall and early spring. This corresponds to the time when productivity in Monterey Bay is decreased and storm activity is greatest (Fig. 6).

It is unknown if beachcast seabirds found on Monterey Bay beaches died within Monterey Bay or if they died outside the Bay and were then transported to Monterey Bay beaches by winds and/or surface currents. It is also possible for seabirds that die atsea to never wash ashore. Seabirds can sink before coming ashore, be transported farther offshore, be scavenged once on the beach, or be missed by observers (Burger \& Fry 1993). During winter, it is possible that beachcast seabirds are swept off beaches and thus not encountered due to the combination of narrow beaches and large wave events. If large numbers of seabirds die outside of Monterey Bay and are transported into the area, this could potentially bias our relative mortality estimates as these birds would not be included in the at-sea survey data. This is potentially problematic for both sooty shearwaters that forage along the California coast during the summer months (Shaffer et al. 2006) as well as common murres that disperse into Monterey Bay at the conclusion of breeding (Stallcup 1976, Croll 1990, Ford et al. 2004). Regardless of these potential problems, it is still valuable to merge these 2 data sets to examine the patterns of mortality and to determine true mortality events: die-offs that cannot be explained by a simple increase in the number of seabirds found offshore, as shown by the northern fulmar event in 2003.

\section{Sooty shearwaters}

Our detailed analysis of sooty shearwater relative mortality patterns (Fig. 4c) confirms our general observation for all seabirds: sooty shearwater relative mortality was best explained by PCs represent- 
ing increased storm activity and decreased productivity.

At-sea seabird density in Monterey Bay is dominated by the presence of sooty shearwaters that migrate to feed in the California Current System during their nonbreeding season (Ainley 1976, Baltz \& Morejohn 1977). The occurrence of sooty shearwaters and common murres in Monterey Bay is likely the result of favorable foraging conditions linked to local environmental processes (Croll 1990, Ainley et al. 2005). Sooty shearwaters arrive in Monterey Bay between May and July, corresponding with intensified upwelling that causes warm surface waters to be advected offshore to be replaced by cold, nutrient-rich, deep waters. This upwelled water results in increased local primary production, ultimately enhancing prey abundance for sooty shearwaters.

Ainley et al. (2005) concluded that sooty shearwater departure from the California Current region is a phenological coincidence rather than a response to available prey reduction in the late summer/early fall. Sooty shearwaters are Southern Hemisphere migrants that forage in the California Current System and Monterey Bay during their non-breeding season. Thus, their density in Monterey Bay is a result of both Southern Hemisphere breeding phenological constraints and favorable foraging conditions in Monterey Bay. Sooty shearwater densities decrease rapidly between August and September as they return to the Southern Hemisphere to breed. Sooty shearwaters that remain in the Monterey Bay region during fall and winter rather than migrate South have disproportionately greater mortality as they experience decreased local productivity and prey availability and increased storm activity. The birds that have remained in Monterey Bay during winter are likely in poor condition: with limited ability to migrate to their Southern Hemisphere breeding colony. However, disproportionately greater mortality during late winter and early spring may result from migrating birds that departed the breeding colonies and arrived in Monterey Bay before the seasonal increase in productivity.

Newman et al. (2007) analyzed $30 \mathrm{yr}$ of seabird necropsy data from the US Geological Service National Wildlife Health Center databases and found that $75 \%$ of pelagic seabird deaths were associated with environmental causes, and of these, 99\% were due to emaciation/starvation. We believe that seabirds, like many other animals such as land birds (i.e. house sparrow Passer domesticus), fishes (i.e. walleye pollock Theragra chalcogramma), and red deer Cervus elaphus, die during the onset of spring when prey availability is low and environmental over-wintering stress is high (Guinness et al. 1978, Johnston \& Fleischer 1981, Kooka et al. 2007).

\section{Common murres}

Common murres did not exhibit the same general pattern we found for all seabirds and sooty shearwaters (Fig. 5). Common murres are resident to the region and are likely dispersed along the coastline and offshore areas during the winter periods of high storm activity and decreased productivity (Briggs et al. 1987). Thus, they may either be less susceptible to these factors or, due to a dispersed distribution, less likely to wash up onto beaches to be counted in beachcast surveys. Common murre breeding sites are to the north (Farallon Islands and Devil's Slide Rock) and south (Hurricane Point) of Monterey Bay, and breeding occurs from April to mid-July (Bockelheide et al. 1990). Therefore, common murres may experience disproportionate mortality during the pre-breeding season (March) as a result of an inability for birds to contend with a winter period of low productivity and high storm activity before the onset of energetically expensive breeding activities.

Numbers of common murres at-sea in Monterey Bay peak as post-breeding birds disperse into Monterey Bay. This explains the maximum density of common murres at-sea and beachcast during August. During this time, male common murres arrive in Monterey Bay with their chicks to feed in the locally productive waters (Stallcup 1976, Croll 1990). Common murre relative mortality values were least during the postbreeding season (August). Recently fledged chicks are likely dying during different times of the year than adults, explaining the slight increase in relative mortality September through November after chicks have arrived in Monterey Bay. Unfortunately, during the fall, it is difficult to accurately distinguish between adults and chicks both during at-sea and beached bird surveys.

Using beachcast and offshore surveys, Forney et al. (2001) demonstrated that common murres in Monterey Bay experienced elevated mortality rates during 1997 and 1998. They conclude that the excessive mortality was due to fisheries interactions that ultimately lead to changes in fisheries regulations. The study by Forney et al. (2001) used a portion of the same data as the current study (1997 to 1998 only); however, they did not statistically test the relationship between the beachcast and offshore seabirds. Although we did not find a significant relationship for relative common murre mortality, we did find that fishing effort was a significant predictor of beachcast common murre density during the set gillnet fishing period of 1997 to 2001. Thus, although fishing effort had an effect on the number of beachcast common murres, disproportionate common murre mortality in Monterey Bay could not be explained by the California halibut set gillnet 
fishery, likely due to the differences between the atsea distribution of common murres and the set gillnet locations.

\section{CONCLUSION}

Monterey Bay is home to a variety of resident and migratory seabirds that are most abundant during the highly productive upwelling season. We found that the most abundant migratory species, the sooty shearwater, experiences greatest relative mortality in Monterey Bay when breeding birds should have already departed for their nest islands, environmental conditions in the Bay are less productive, and storm activity has increased. Mortality of the resident species we tested, the common murre, was more consistent yearround, and in general was not directly linked to oceanographic conditions but may be explained by a combination of environmental factors and seasonal reproductive stresses (i.e. lack of prey availability).

Although many seabirds become beachcast during the upwelling and oceanic seasons, linking these data to their offshore density is critical in determining whether or not they are dying disproportionately to their numbers offshore. Although beachcast seabird studies have been conducted for decades to examine mortality patterns of seabird populations, this is the first study that has combined beachcast seabird data with at-sea seabird density data to examine seabird mortality relative to the numbers of seabirds offshore. This link to offshore seabirds can help elucidate the important factors in determining at-sea mortality patterns of seabirds during the non-breeding period. In addition, it can aid management agencies in the determination of a true high mortality event (natural or anthropogenic) that may or may not require additional investigation. These linkages can best be determined by concurrent long-term data sets.

Acknowledgements. We would thank the hundreds of BeachCOMBERS and Wind to Whales volunteers who have spent countless hours collecting the seabird data. We thank the crew of the RV 'John H. Martin' for their logistical support. P. Raimondi, K. Forney, R. Kudela, B. Marinovic, and J. Carretta provided data and insight on statistical analyses and environmental variables. The BeachCOMBERS project is funded by the Monterey Bay National Marine Sanctuary (to J.T.H.). Additional funding for this project was provided by the Center for Integrated Marine Technology, University of California, Santa Cruz through NOAA grant NA160C2936, the California Department of Fish and Game's Oil Spill Response Trust Fund through the Oiled Wildlife Care Network at the Wildlife Health Center, School of Veterinary Medicine, University of California, Davis award number 99123942, and the Monterey Bay Sanctuary Foundation award number SC-06-55.

\section{LITERATURE CITED}

Ainley DG (1976) The occurrence of seabirds in the coastal region of California. West Birds 7:33-68

> Ainley DG, Spear LB, Tynan CT, Barth JA, Pierce SD, Ford RG, Cowles TJ (2005) Physical and biological variables affecting seabird distributions during the upwelling season of the northern California Current. Deep-Sea Res II 52:123-143

Baltz DM, Morejohn GV (1977) Food habits and niche overlap of sea birds wintering on Monterey Bay, California. Auk 94:526-543

Behrenfeld MJ, Falkowski PG (1997) Photosynthetic rates derived from satellite-based chlorophyll concentration. Limnol Oceanogr 42:1-20

Benson SR (2002) Ecosystem studies of marine mammals and seabirds in Monterey Bay, CA, 1996-99. MSc thesis, San Jose State University

Bertram DF, Jones IL, Cooch EG, Knechtel HA, Cooke F (2000) Survival rates of Cassin's and rhinoceros auklets at Triangle Island, British Columbia. Condor 102:155-162

Bockelheide RJ, Ainley DG, Morrell SH, Huber HR, Lewis TJ (1990) Common Murre. In: Ainley DG, Bockelheide RJ (eds) Seabirds of the Farallon Islands. Stanford University Press, Stanford, CA, p 245-275

Briggs KT, Tyler WB, Lewis DB, Carlson DR (1987) Bird communities at sea off California: 1975 to 1983. Stud Avian Biol 11:1-74

Brooke MdeL (2004) The food consumption of the world's seabirds. Proc R Soc Lond B Biol Sci 271:S246-S248

Buckelew SL (2007) The impacts of biological traits and anthropogenic traits on seabird extinction risks. MSc thesis, University of California

Buckland ST, Anderson DR, Burnham KP, Laake JL, Borchers DL, Thomas L (2001) Introduction to distance sampling: estimating abundance of biological populations. Oxford University Press, New York, NY

Burger AE, Fry DM (1993) Effects of oil pollution on seabirds in the northeast Pacific. In: Vermeer K, Briggs KT, Morgan $\mathrm{KH}$, Siegel-Causey D (eds) The status, ecology, and conservation of marine birds in the North Pacific. Canadian Wildlife Service Special Publications, Ottawa, p 254-263

Camphuysen CJ, Heubeck M (2001) Marine oil pollution and beached bird surveys: the development of a sensitive monitoring instrument. Environ Pollut 112:443-461

Croll DA (1990) Physical and biological determinants of the abundance, distribution, and diet of the common murre in Monterey Bay, California. Stud Avian Biol 14:139-148

Croll DA, Tershy BR, Hewitt RP, Demer DA and others (1998) An integrated approach to the foraging ecology of marine birds and mammals. Deep-Sea Res II 45:1353-1371

Dulvy NK, Sadovy Y, Reynolds JD (2003) Extinction vulnerability in marine populations. Fish Fish 4:25-64

Fleet DM (2006) A review of beached bird surveys within the Wadden Sea trilateral monitoring and assessment program. Mar Ornithol 34:129-132

Ford RG, Ainley DG, Casey JL, Keiper CA, Spear LB, Ballance LT (2004) The biogeographic patterns of seabirds in the central portion of the California Current. Mar Ornithol 32:77-96

Forney KA, Benson SR, Cameron GA (2001) Central California gillnet effort and bycatch of sensitive species, 1990-1998. In: Melvin EF, Parrish JK (eds) Seabird bycatch: Trends, roadblocks, and solutions. University of Alaska Sea Grant College Program Report, Fairbanks, AK, p 141-160

Graham MH (2003) Confronting multicollinearity in ecological multiple regression. Ecology 84:2809-2815 
Guinness FE, Cluttonbrock TH, Albon SD (1978) Factors affecting calf mortality in Red Deer (Cervus elaphus). J Anim Ecol 47:817-832

Harris RJ, Tseng FS, Pokras MA, Suedmeyer BA, Bogart JSH, Prescott RL, Newman SH (2006) Beached bird surveys in Massachusetts: the seabird ecological assessment network (SEANET). Mar Ornithol 34:115-122

Heinemann D (1981) A range finder for pelagic bird censusing. J Wildl Manage 45:489-493

Heubeck M (2006) The Shetland beached bird survey, 1979 2004. Mar Ornithol 34:123-127

> Hewitt RP, Demer DA (1993) Dispersion and abundance of Antarctic krill in the vicinity of Elephant Island in the 1992 austral summer. Mar Ecol Prog Ser 99:29-39

IUCN (2007) 2007 IUCN Red list of threatened species. Accessed 22 Oct 2007. Available at www.iucnredlist.org

Johannesson KA, Mitson RB (1983) Fisheries acoustics: a practical manual for aquatic biomass estimation. FAO Fish Tech Pap 240

Johnston RF, Fleischer RC (1981) Overwinter mortality and sexual size dimorphism in the house sparrow. Auk 98: 503-511

Kooka K, Yamamura O, Andoh T (2007) Rate of energy depletion and overwintering mortality of juvenile walleye pollock in cold water. J Fish Biol 71:1714-1734

Kudela RM, Cochlan WP, Peterson TD, Trick CG (2006a) Impacts on phytoplankton biomass and productivity in the Pacific Northwest during the warm ocean conditions of 2005. Geophys Res Lett 33:L22S06

Kudela RM, Garfield N, Bruland KW (2006b) Bio-optical signatures and biogeochemistry from intense upwelling and relaxation in coastal California. Deep-Sea Res II 53: 2999-3022

Marinovic BB, Croll DA, Gong N, Benson SR, Chavez FP (2002) Effects of the 1997-1999 El Nino and La Nina events on zooplankton abundance and euphausiid community composition within the Monterey Bay coastal upwelling system. Prog Oceanogr 54:265-277

Mason JW (1997) Distribution and abundance of seabirds in Monterey Bay, California. MSc thesis, California State University

Nevins HM, Harvey JT (2003) Preliminary Report: mortality of northern fulmars (Fulmarus glacialus) in Monterey Bay during winter 2003. Report to the Monterey Bay National

Editorial responsibility: Hans Heinrich Janssen, Oldendorf/Luhe, Germany
Marine Sanctuary, Monterey, CA

Newman SH, Chmura A, Converse K, Kilpatrick AM, Patel N, Lammers E, Daszak P (2007) Aquatic bird disease and mortality as an indicator of changing ecosystem health. Mar Ecol Prog Ser 352:299-309

> Oedekoven CS, Ainley DG, Spear LB (2001) Variable responses of seabirds to change in marine climate: California current, 1985-1994. Mar Ecol Prog Ser 212: $265-281$

Parrish JK, Bond N, Nevins H, Mantua N, Loeffel R, Peterson WT, Harvey JT (2007) Beached birds and physical forcing in the California Current System. Mar Ecol Prog Ser 352: $275-288$

Quinn GP, Keough MJ (2002) Experimental design and data analysis for biologists. Cambridge University Press, Cambridge

Roletto J, Mortenson J, Harrald I, Hall J, Grella L (2003) Beached bird surveys and chronic oil pollution in central California. Mar Ornithol 31:21-28

Shaffer SA, Tremblay Y, Weimerskirch H, Scott D and others (2006) Migratory shearwaters integrate oceanic resources across the Pacific Ocean in an endless summer. Proc Natl Acad Sci USA 103:12799-12802

Skogsberg T (1936) Hydrography of Monterey Bay, California. Thermal conditions, 1929-1933. Trans Am Philos Soc 29: $1-152$

Skogsberg T, Phelps A (1946) Hydrography of Monterey Bay, California. Thermal conditions, Part II (1934-1937). Proc Am Philos Soc 90:350-386

Spear L, Nur N, Ainley DG (1992) Estimating absolute densities of flying seabirds using analyses of relative movement. Auk 109:385-389

Stallcup RW (1976) Pelagic birds of Monterey Bay California. West Birds 7:113-136

SYSTAT (2007) Systat 12. Systat Software, Inc.

- Wooller RD, Bradley JS, Croxall JP (1992) Long-term population studies of seabirds. Trends Ecol Evol 7:111-114

> Yen PPW, Sydeman WJ, Hyrenbach KD (2004) Marine bird and cetacean associations with bathymetric habitats and shallow-water topographies: implications for trophic transfer and conservation. J Mar Syst 50:79-99

Zydelis R, Dagys M, Vaitkus G (2006) Beached bird surveys in Lithuania reflect marine oil pollution and bird mortality in fishing nets. Mar Ornithol 34:161-166

Submitted: August 22, 2008; Accepted: June 9, 2009

Proofs received from author(s): October 7, 2009 